\title{
ISOLATION AND IDENTIFICATION OF DEFENSIVE FLAVONOIDS FROM BRASSICA NAPUS LEAVES EXTRACT WITH PROMISING BIOLOGICAL ACTIVITY TO CONTROL THE COTTON LEAFWORM, SPODOPTERA LITTORALIS (BOISD.)
}

\author{
ANWAAR M. ABAZA \\ Plant Protection Research Institute, ARC, Dokki, Giza, Egypt. \\ (Manuscript received 17 December 2017)
}

\begin{abstract}
$B$ rassica napus plant has defensive secondary metabolites against phytophagous insects and pathogens. In extraction process, the end product contains traces of residual solvent, so, the solvent should not be non-toxic and should not interfere with the bioassay. The preliminary biological activity of ethanol, petroleum ether, methylene chloride, ethyl acetate and butanol fractions of $B$. napus leaves was investigated against the $4^{\text {th }}$ instar larvae of Spodoptera littoralis under laboratory conditions. The ethanolic fraction showed the most toxic effect against the $4^{\text {th }}$ instar larvae of $S$. littoralis. By phytochemical screening, B. napus leaves contain flavonoids as a major constituent. Four flavonoid compounds were isolated as crystals by column chromatographic technique using silica gel and purified on Sephadex LH-20. Their structures were elucidated as Quercetin (1), Kaempferol (2), Kaempferol-3-O-g/ucoside (3) and Quercetin-7-O-glucoside (4) by using UV and ${ }^{1} \mathrm{H}-\mathrm{NMR}$ techniques. On toxicological studies, $\mathrm{LC}_{50}$ values $(0.455$ and $0.091 \mathrm{gm} / 100 \mathrm{ml})$ at 7 and 14 days post treatment, respectively, showed that the toxicity of $B$. napus extract increased with increasing concentration and time post treatment. This indicated that $B$. napus extract can be used as green insecticide to control the cotton leafworm, $S$. littoralis.

Keywords: Brassica napus, defensive secondary metabolites, flavonoids, column chromatograhy UV, ${ }^{1} \mathrm{H}-\mathrm{NMR}$, cotton leafworm, Spdoptera littoralis.
\end{abstract}

\section{INTRODUCTION}

The environmental problems caused by overuse of pesticides have been the matter of concern for both scientists and public in recent years due to the high toxicity and non-biodegradable properties of pesticides, the residues in soil, water resources and crops that affect human health.

The move toward green chemistry processes need for developing new crop protection tools with novel modes of action makes discovery and commercialization of natural products as green pesticides. Natural products are excellent alternative to synthetic pesticides as a mean to reduce negative impacts to human health and the environment. 
The concept of "Green pesticides" refers to all types of nature-oriented and beneficial pest control materials that can contribute to reduce the pest population and increase food production. They are more compatible with the environment components than synthetic pesticides (Isman and Machial, 2006).

Plants produce a great variety of secondary metabolites including terpenoids, alkaloids, steroids, flavonoids, tannins and saponnins are often important for mediating interactions between plants and their biotic environment (Kessler and Baldwin, 2002). They can be models of active defense against phytophagous insects and pathogens.

Phenolic compounds are a large group of secondary metabolites widespread in the plant kingdom. They can be classified into simple phenols, phenolic acids, hydroxycinnamic acid derivatives and flavonoids, depending on their structure.

Flavonoids are a ubiquitous and widely distributed group of natural products found in plants, they have been classified into different types of structures according to differences in aglycone, sugar moieties, inter-saccharide linkage and glycosylation position.

The most flavonoids that possessing fifteen carbon atoms with two aromatic rings joined by a linear three carbon chain. It can be described as a series of $C_{6}-C_{3}-$ $C_{6}(1)$. The chemical structure of flavonoids is based on $C_{15}$ skeleton with a chromane ring bearing a second aromatic ring $B$ in position 2,3 or 4 (2). In a few cases, the sixmembered heterocyclic ring $C$ occurs in an isomeric open form or is replaced by a five-membered ring (3). The oxygen bridge involving the central carbon atom $\left(C_{2}\right)$ of the 3C-chain occurs in a rather limited numbers of cases, where the resulting heterocyclic is of the furan type.

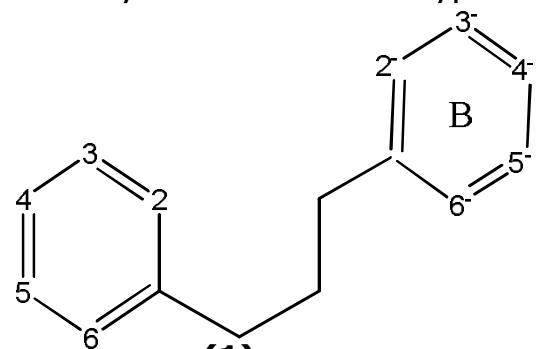

(1)<smiles>c1ccpcc1</smiles>

(2) 
Flavonoids play important roles in plant biochemistry and physiology, acting as antioxidants, enzyme inhibitors and precursors to toxic substances, besides having long been recognized as possessing anti-allergic, anti-inflammatory, anti-viral, antiproliferative and anti-carcinogenic activities in animals (Nijveldt et al., 2001)

In Egyptian fields we observed that, canola (Brassica napus) plant has defensive secondary metabolites against insects; especially lepidopteran cotton leafworm, Spodoptera littoralis, which has its importance as one of the most destructive phytophagous lepidopterous pests in Egypt.

Brassica napus is a member Brassicaceae family which consists of 350 genera and about 3.500 species, it is known that seeds of winter rapeseed (B. napus) contain high amount of phenolic compounds. In fact, canola seeds are much richer than in phenolic compounds compared to other oilseeds (Padillia et al., 2007).

In extraction process, successful determination of biologically active compound from plant material is largely dependent on the type of solvent used in the extraction procedure. Properties of a good solvent in plant extractions include low toxicity, ease of evaporation at low heat, promotion of rapid physiologic absorption of the extract, preservative action and inability to cause the extract to complex or dissociate. As the end product in extraction will contain traces of residual solvent, the solvent should be non-toxic and should not interfere with the bioassay Ncube et al., (2008). Initial screening of plants for possible insecticidal and antimicrobial activities typically begins by using the crude or alcohol extractions and can be followed by various organic solvent extraction methods.

This study was directed to investigate the biological activity of $B$. napus leaves extract against the cotton leafworm, $S$. littoralis. Isolation and purification of bioactive flavonoids using Column Chromatography (CC), Thin Layer Chromatography (TLC) and Sephadex LH-20. Structure identification of isolated flavonoids using different spectral methods as UV and ${ }^{1} \mathrm{H}$-NMR techniques.

\section{MATERIALS AND METHODS}

\section{Materials}

\section{a. Plant material}

Brassica napus leaves were collected from a field of experimental farm in agricultural research institute, Ismailia governorate, washed to clean and left to dry under room temperature. The dried leaves were homogenized to fine powder by using electric mill. 


\section{b. Solvents}

Ethanol, ethyl acetate, methylene chloride, petroleum ether and n-butanol were obtained from Edwic Company.

\section{c. Insect}

S. littoralis strain used in this study is a laboratory susceptible strain reared in the plant protection research institute, Dokki, Giza, Egypt according to EL-Defrawi et al., (1964). The culture was maintained in climatic chamber under optimum conditions $25 \pm 2^{\circ} \mathrm{C}, 75 \pm 5 \%$ R.H and (16L:8D) light: dark photoperiod, where reared on fresh castor bean leaves. The newly molted $4^{\text {th }}$ instar larvae were selected for this study.

\section{Instrumentations}

${ }^{1} \mathrm{H}-\mathrm{NMR}$ spectra were measured by $300 \mathrm{MHz}-\mathrm{NMR}$ spectrometer (at Cairo University, Nuclear Magnetic Resonance Laboratory), chemical shifts are given in $\delta$ (ppm) relative to TMS as internal standard compound. UV spectra were recorded on a Shimadzu 240-PC spectrometer (at the National Research Center). CC Column Chromatography was performed on silica gel Merck grain size $0.2-0.063 \mathrm{~nm}$ and on Sephadex LH-20. TLC Thin Layer Chromatography was carried out with Silica gel GF 254 pre-coated plates $20 \times 20 \mathrm{~cm}$ on aluminum sheets. The isolated compounds were sprayed with $10 \%$ sulfuric acid and were visualized on plates under UV lamp at 254 and $365 \mathrm{~nm}$ lamp.

\section{Extraction}

Dried leaves powder $(400 \mathrm{~g}$ ) was extracted by soaking at room temperature in ethanol $60 \%(\mathrm{v} / \mathrm{v})$. The resulting extract was filtrated and evaporated under vacuum at $40^{\circ} \mathrm{C}$ by using rotary evaporator to give ethanol extract $(65.8 \mathrm{~g})$ as a dark green residue. Part of the extract $(30 \mathrm{~g})$ was dissolved in least amount of ethanol ( $~ 10 \mathrm{ml}$ ) and suspended in distilled water and subjected to sequential liquid-liquid extraction with petroleum ether, methylene chloride, ethyl acetate, and n-butanol.

We used ethanol solvent in the extraction process, the choice will also depend on the targeted compounds to be extracted, the flavonoid and phenolic acid compounds were affected by the concentration of ethanol solvent. The single-factor experiment showed that $60 \%$ ethanol was suitable to extract the phenolic constituents from the plant. The levels of phenolic contents were decreased as the concentration of ethanol increased Harborne (1984); Harmala et al., (1992).

\section{Preparation of tested concentrations}

The residues were diluted in distilled water containing one drop of an emulsifier Tween ${ }^{\circledR} 20$ (Tween ${ }^{\circledR}$ 20; Sigma-Aldrich), to ensure complete solubility of the material in water. The concentrations used were selected after preliminary bioassays with a wide range of concentrations to determine the range needed. After 
the proper range was obtained, at least five serially diluted concentrations covering the range $10-90 \%$ mortality were prepared.

Two negative control treatments were used in each experiment. The one was one drop of emulsifier $\left(\operatorname{Tween}^{\circledR} 20\right)$ in water, since the Tween ${ }^{\circledR} 20$ solutions showed no significant mortality effect against the $S$. littoralis larvae (data not shown) compared with water.

\section{Biological studies}

Leaf dipping technique was applied; Castor bean leaves were dipped for 30 seconds in each concentration of ethanol extract and fractions then left to dry. The treated leaves were offered to newly molted $4^{\text {th }}$ instar larvae of $S$. littoralis for $48 \mathrm{hrs}$ then replaced by untreated ones. Accumulative mortality percentages were recorded till 7 and 14 days post treatment, then corrected according Abbott's formula (1925). From the corrected mortality percentages the corresponding toxicity lines (LC-P lines) were estimated in addition to determine $\mathrm{LC}_{25}$ and $\mathrm{LC}_{50}$ values and their confidence limits, slope values of tested extract were also estimated.

\section{Abbott's formula}

Corrected mortality percentage $=\mathrm{T}-\mathrm{C} / 100-\mathrm{C}$

Where; T: Larval mortality percentage in treatment

C: Larval mortality percentage in control.

\section{Preliminary phytochemical screening of $B$. napus extract}

Phytochemical screening of $B$. napus leaves extract was performed by following standard procedures (Sofowara, 1993; Harborne, 1998); In brief, $0.5 \mathrm{ml}$ of extract was added with a drop or two of Mayer's regent by the side of test tube and the formation of white to yellowish precipitate indicates presence of alkaloids. Appearance of faint pink to dense pink color within three minutes after addition of 1 $\mathrm{ml}$ of extract with conc. Hydrochloric acid and magnesium powder indicates presence of flavonoids. Change of color from violet to blue or green (lower layer) after the addition of $2 \mathrm{ml}$ of acetic anhydride and sulphuric acid gives positive result for steroids.

Addition of $2 \mathrm{ml}$ of chloroform and $3 \mathrm{ml}$ of conc. sulphuric acid to the extract and formation of reddish brown layer at the junction of two solutions confirms presence of terpenoids. Existence of froth formation during warming and vigorous shaking indicates presence of saponins. Appearance of brownish green or blue black coloration after adding $0.1 \%$ ferric chloride to the cooled extract indicates tannins.

\section{Phytochemical study of ethanol extract}

From preliminary biological studies, the most toxic fraction of $B$. napus leaves against the $4^{\text {th }}$ instar of $S$. littoralis was studied phytochemically in details. 


\section{Isolation of flavonoids from $B$. napus leaves extract}

The extract was chromatographed using column chromatography on a Silica gel eluted with chloroform-methanol starting from 10:0 to 4:1 gradually; eluted fractions were combined on their TLC pattern to yield nine fractions. The chloroform-methanol sub-fraction (9:1) was purified on a Sephadex LH-20 column eluted with chloroformmethanol (1:1) to yield pure compounds (1) and (2). The chloroform-methanol sub fraction (6:4) chromatographed on a Sephadex LH-20 column eluted with methanol and further purified using preparative TLC developed in a mixture of $\mathrm{CHCl}_{3} / \mathrm{MeOH}$ $(6: 4, v / v)$ yielded compounds (3) and (4) (Harborne and Mabry, 1982).

\section{Investigation of the sugar moiety of isolated flavonoids}

The aqueous acidic mother-liquor remained after extraction with ethyl acetate was neutralized with excess barium carbonate, then filtered. The filtrate after removal of the precipitated barium sulphate was evaporated under vacuum, the residue contained the sugar moiety (glycone) was then dissolved in $10 \%$ isopropanol. The alcoholic solution was subjected to paper-chromatography using various monosaccharides samples for comparison as authentic (glucose, galactose, xylose, rhamanose and arabinose). The paper chromatogram was developed twice with nbutanol-acetic acid-water (40:10:50) upper layer. Detection was carried out by spraying with aniline / phthalic acid reagent and heating at $110^{\circ} \mathrm{C}$ in an oven, a brown to reddish-brown colored spots were developed.

\section{UV-measurements of isolated flavonoids}

The UV absorption of isolated flavonoids was measured according to (Horowitz and Jurd 1961; Mabry et al., 1970; Mears and Mabry 1972). Flavonoids contain conjugated aromatic system and show intense absorption bands in UV and visible regions of spectrum. The absorption spectra of isolated flavonoids were measured using Shimadzu 2401-PC spectrometer. A stock solution of the flavonoid substance was prepared by dissolving a small amount of the compound (about 0.1 $\mathrm{mg}$ ) in about $10 \mathrm{ml}$ of spectroscopic methanol. The concentration was adjusted so that the optical density of the major absorption peak between 240 and $400 \mathrm{~nm}$ gave an optical density (OD) reading in the region 0.6 to 0.8 .

\section{Stock Solutions and Solids reagents for UV- analysis}

- Sodium Methoxide (NaOMe): Freshly cut metallic sodium $(2.5 \mathrm{~g})$ was added in small portions to dry spectroscopic methanol $(100 \mathrm{ml})$. The solution was stored in a glass container with tightly fitting plastic stopper.

- Aluminium Chloride $\left(\mathrm{AlCl}_{3}\right)$ : Five grams of fresh anhydrous reagent grade $\mathrm{AlCl}_{3}$ were added cautiously to spectroscopic methanol $(100 \mathrm{ml})$. 
- Hydrochloric Acid ( $\mathrm{HCl})$ : Concentrated reagent grade hydrochloric acid $(50 \mathrm{ml}$ ) was mixed with distilled water $(100 \mathrm{ml})$; the solution was stored in a glass stopped bottle. - Sodium Acetate ( $\mathrm{NaOAc}$ ): Anhydrous powdered reagent grade sodium acetate was used.

- Boric Acid $\left(\mathrm{H}_{3} \mathrm{BO}_{3}\right)$ : Anhydrous powdered reagent grade boric acid was used.

\section{Procedure of UV- measurements}

1. The methanol spectrum was measured at normal scan speed (about $50 \mathrm{~nm} /$ min.) using 2-3 $\mathrm{ml}$ of the stock solution of the flavonoid.

2. The sodium methoxide was measured immediately after the addition of three drops of sodium methoxide stock solution to the solution used for step 1, and after $5 \mathrm{~min}$. the spectrum was rerun to check for flavonoid decomposition.

3. The aluminum chloride spectrum was measured immediately after the addition of three drops of the aluminum chloride stock solution to $2-3 \mathrm{ml}$ of fresh stock solution of the flavonoid.

4. The aluminum chloride / hydrochloric acid spectrum was recorded immediately after the addition of three drops of the stock hydrochloric acid solution to the solution used for step 3.

5. The NaOAc spectrum was determined by the addition of excess coarsely powdered anhydrous sodium acetate to $2-3 \mathrm{ml}$ fresh stock solution of the flavonoid and shaking the cuvette, (about $2 \mathrm{~mm}$ layer of sodium acetate remained at the bottom of the cuvette), and the spectrum was recorded within 2 min. then it was rerun after 5-10 min. to check the flavonoid decomposition.

6. The sodium acetate / boric acid spectrum was determined by the addition of sufficient powdered anhydrous boric acid to give a saturated solution to the cuvette from step 5 containing the sodium acetate.

\section{RESULTS AND DISCUSSION}

Leaves of canola (Brassica napus) were used in this study due to the noneconomically importance of the plant's leaves, we observed that B. napus plant has self defense property in field against insects especially lepidopteran cotton leafworm, Spodoptera littoralis. B. napus may be containing defensive secondary metabolites against insects, so its leaves extract could be used as botanical insecticide against $S$. littoralis.

Flavonoids have multiple additional roles in plants, including attracting insects for seed dispersion and pollination. They are also part of the natural defense system against insects, fungi, viruses and bacteria and they act as plant hormone controller. Also they have been reported to possess many useful properties for human health, including anti-inflammatory, enzyme inhibition, antimicrobial, vascular and cytotoxic 
antitumor activity, but the most action of flavonoids their antioxidant activity (Chu et al., 2000).

\section{Preliminary biological activity}

The $B$. napus leaves ethanolic extract and its fractions; petroleum ether, methylene chloride, ethyl acetate, and $n$-butanol were investigated for their biological activity as insecticides against the $4^{\text {th }}$ instar larvae of $S$. littoralis under laboratory conditions.

Table 1 . The preliminary insecticidal activity of $B$. napus leaves extracts at conc. (1gm / $100 \mathrm{ml}$ ) against $4^{\text {th }}$ instar larvae of $S$. littoralis at 7 and 14 days post treatment.

\begin{tabular}{|l|c|c|}
\hline \multirow{2}{*}{ Extract } & \multicolumn{2}{|c|}{ Mortality percentages \% } \\
\cline { 2 - 3 } & 7-Days post treatment & 14- Days post treatment \\
\hline Ethanol & $60 \pm 4.3$ & $86.0 \pm 5.9$ \\
\hline Petroleum ether & $42.0 \pm 9.0$ & $67.67 \pm 8.1$ \\
\hline Methylene chloride & $33.33 \pm 5.9$ & $40.0 \pm 7.5$ \\
\hline Ethyl acetate & $40.0 \pm 4.7$ & $55.7 \pm 4.3$ \\
\hline n-butanol & $10.0 \pm 2.3$ & $20.0 \pm 5.9$ \\
\hline
\end{tabular}

The preliminary insecticidal activity of concentration $1 \mathrm{gm} / 100 \mathrm{ml}$ for each extract at 7 and 14 days post treatment revealed that ethanol extract is the most toxic extract followed by petroleum ether, ethyl acetate, methylene chloride and finally butanol extract against the $4^{\text {th }}$ instar larvae of $S$. littoralis under laboratory conditions. So, the ethanolic extract of $B$. napus leaves is the promising extract therefore, it was selected to be studied in details.

\section{Preliminary phytochemical screening}

Phytochemical screening of $B$. napus extract revealed the presence of flavonoids as a major constituent; steroids and terpenoids.

\section{Isolation and identification of flavonoids}

The isolated compounds were identified using UV and ${ }^{1} \mathrm{H}-\mathrm{NMR}$ spectral data, and determined as Quercetin (1), Kaempferol (2), Kaempferol-3-O-glucoside (3) and Quercetin-7-O-glucoside (4) as follow;

The UV spectra of most flavonoids consists of two major absorption maxima; one of which occurs in the range $240-285 \mathrm{~nm}$ (Band-II) and the other range 300-400 $\mathrm{nm}$ (Band-I). In general terms Band-II absorption may be considered as having originated from A- ring (benzoyl system) and Band-I from B-ring (cinnamoxyl system) (Jangaard, 1970). 


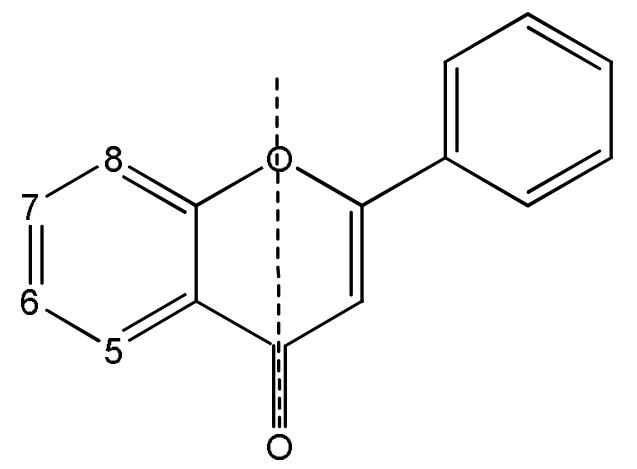

II

I

\section{Benzoyl Cinnamoxyl}

\section{Structure elucidation of compound (1)}

Compound (1) was isolated and purified as yellow crystals. The UV spectrum in methanol showed two major absorption bands at $\lambda_{\max }(256$ and $370 \mathrm{~nm})$ as shown in Table (2), indicator for this compound is flavonol, moreover, Band-II at $\lambda_{\max }$ (256 $\mathrm{nm}$ ) indicated the presence of two oxygen atoms in B-ring.

Table 2. UV-absorption spectrum of compound (1)

\begin{tabular}{|c|c|c|c|c|c|c|}
\hline Band & $\mathrm{MeOH}$ & $\mathrm{NaOH}$ & $\mathrm{NaOAC}$ & $\mathrm{NaOAc} / \mathrm{H}_{3} \mathrm{BO}_{3}$ & $\mathrm{AlCl}_{3}$ & $\mathrm{AlCl} / \mathrm{HCl}$ \\
\hline B-II & 256 & 267 & 267 & 277 & 281 & 280 \\
\hline B-I & 370 & 426 & 425 & 391 & $340-441 \mathrm{sh}$ & $340-428 \mathrm{sh}$ \\
\hline
\end{tabular}

In addition of sodium hydroxide $(\mathrm{NaOH})$ caused a bathochromic shift which leads to absorption Band-I ( $\lambda_{\max } 426 \mathrm{~nm}$ ), this proved the presence of free 4l-OH group, also a bathochromic shift which leads to absorption Band-II (267 nm) indicator for free $7-\mathrm{OH}$ group, where $\mathrm{NaOH}$ is strong base that ionizes to some extend all hydroxyl groups on the flavonoid nucleus. Hence, for most hydroxylated flavonoids, shifts to longer wavelength are observed in both bands (Horowitz and Jurd, 1961).

Addition of sodium acetate ( $\mathrm{NaOAc}$ ) caused a bathochromic shift in Band-II $(267 \mathrm{~nm}$ ) indicated presence of free 7-OH group. Addition of boric acid caused a bathochromic shift in Band-I (391 nm) which proved the presence of catecholic $\mathrm{OH}$ groups. This is compatible with Mabry et al., (1970), where sodium acetate is a weaker base than sodium hydroxide and tend to ionize significantly only the more acidic phenolic hydroxyl groups (i.e. the 3,7- and $4 \backslash$ - hydroxyl groups).

After addition of aluminum chloride $\left(\mathrm{AlCl}_{3}\right)$, high bathochromic shift leading absorption Band-I $(340,441 \mathrm{sh})$ indicated the presence of free 5 and 7-OH groups. The hypsochromic shift of $\mathrm{AlCl}_{3}$ spectrum in Band-I (340, $428 \mathrm{sh}$ ) after addition of $\mathrm{HCl}$, this indicated the presence of free ortho $3 \backslash, 4 \backslash-\mathrm{OH}$ groups in ring $\mathrm{B}$. Where aluminium chloride chelates with functional groups such as 5-hydroxyl-4-keto, 3-hydroxyl-4-keto and o-dihydroxy-systems and this reaction is evidenced by bathochromic shift of one 
or both bands in the spectrum. In presence of small amounts of aqueous acid, the complexes formed with o-dihydroxyl groups and the 3-hydroxyl-4-keto system in dihydroflavonols decomposes. When o-dihydroxyl groups are present in the flavonoid together with 5- or 3-hydroxyl, a double complex is formed. Traces of water in ethanol (but not in methanol) prevent the formation of Al-o-dihydroxyl complexes. Methanol is thus the solvent of choice for spectral detection of o-di-hydroxyl groups (Mears and Mabry, 1972).

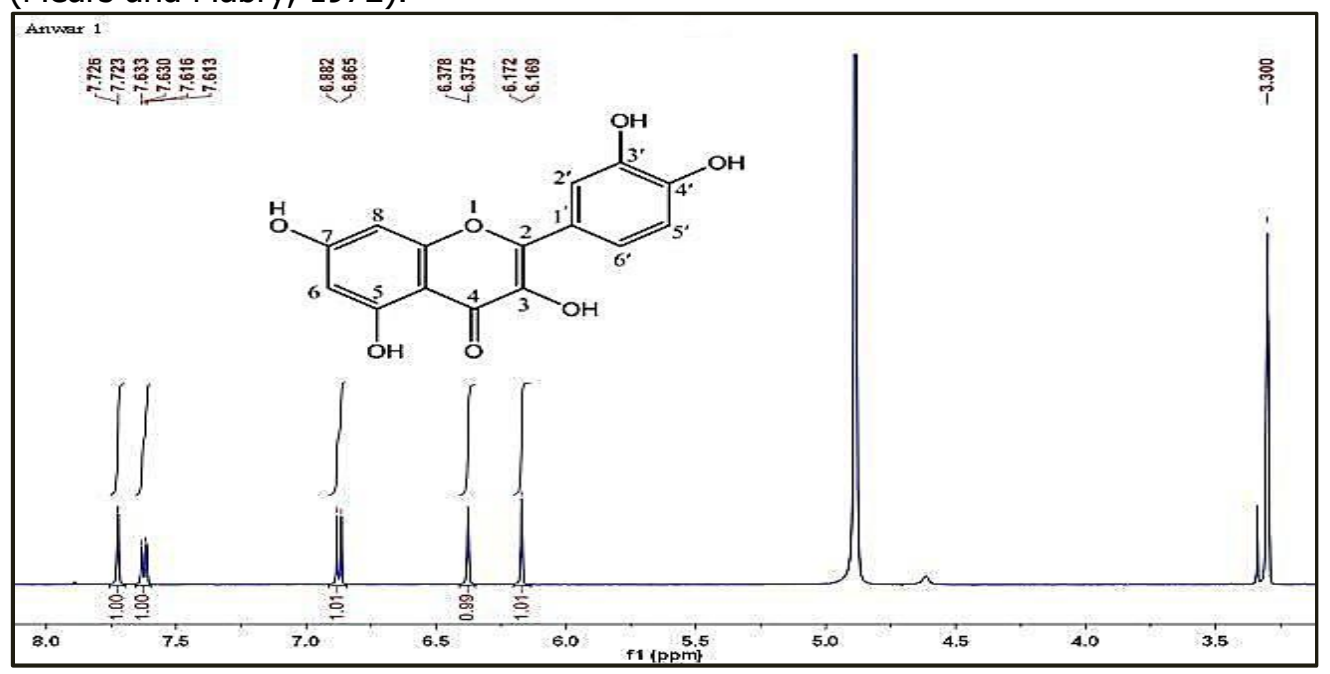

Fig. 1. ${ }^{1} \mathrm{H}-\mathrm{NMR}$ spectrum of compound 1 (Quercetin).

The ${ }^{1} \mathrm{H}-\mathrm{NMR}$ spectrum of compound (1) was characteristic for favonol as shown in Table (6) and Fig. (1), it showed two signals at $\delta 6.17(1 \mathrm{H}, d)$ and $6.37 \mathrm{ppm}$ $(1 \mathrm{H}, d)$ consistent with the meta protons $\mathrm{H}-6$ and $\mathrm{H}-8$ on A-ring, On the other hand, the observation of $A B X$ system at $7.72\left(1 \mathrm{H}, d, \mathrm{H}-2^{\prime}\right), 7.61(1 \mathrm{H}, d d, \mathrm{H}-6 \mathrm{l})$, and 6.88 $\left(1 \mathrm{H}, d, \mathrm{H}-5^{\mathrm{I}}\right)$ corresponding to the catechol protons on B-ring. All spectral data of compound (1) showed that the compound is Quercetin were compatible with those of Dhasan et el., (2008).

\section{Structure elucidation of compound (2)}

Compound (2) was isolated and purified as yellow crystals. The UV spectrum in methanol showed two absorption Bands at $\lambda_{\max }(275$ and $366 \mathrm{~nm})$ as shown in Table (3), indicator for this compound is flavonol.

Table 3. UV-absorption spectrum of compound (2)

\begin{tabular}{|c|c|c|c|c|c|c|}
\hline Band & $\mathrm{MeOH}$ & $\mathrm{NaOH}$ & $\mathrm{NaOAC}$ & $\mathrm{NaOAc} / \mathrm{H}_{3} \mathrm{BO}_{3}$ & $\mathrm{AlCl}_{3}$ & $\mathrm{AlCl} / \mathrm{HCl}$ \\
\hline B-II & 275 & 284 & 285 & 285 & 280 & 280 \\
\hline B-I & 366 & 420 & 380 & 380 & 340 & 340 \\
\hline
\end{tabular}

The addition of sodium hydroxide $(\mathrm{NaOH})$ caused a bathochromic shift which leads to absorption Band-I at $\lambda_{\max }(420 \mathrm{~nm})$, this proved the presence of free 4l-OH group, 
also a bathochromic shift which leads to absorption Band-II (284 nm) indicator for free 7-OH group.

After addition of sodium acetate, a bathochromic shift was observed in the spectrum of Band-II (285 nm) indicated presence of free 7-OH group. Addition of boric acid caused no shift in Band-II (285 nm) which proved the absence of any catecholic $\mathrm{OH}$ - groups.

In addition of aluminum chloride $\left(\mathrm{AlCl}_{3}\right)$, a bathochromic shift leading absorption Band-II $(280 \mathrm{~nm})$ indicated the presence of free 5 and 3-OH groups. No change was observed in Band-I (380 nm) of $\mathrm{AlCl}_{3}$ spectrum after addition of $\mathrm{HCl}$ indicating the absence of any catecholic $\mathrm{OH}$ - groups.

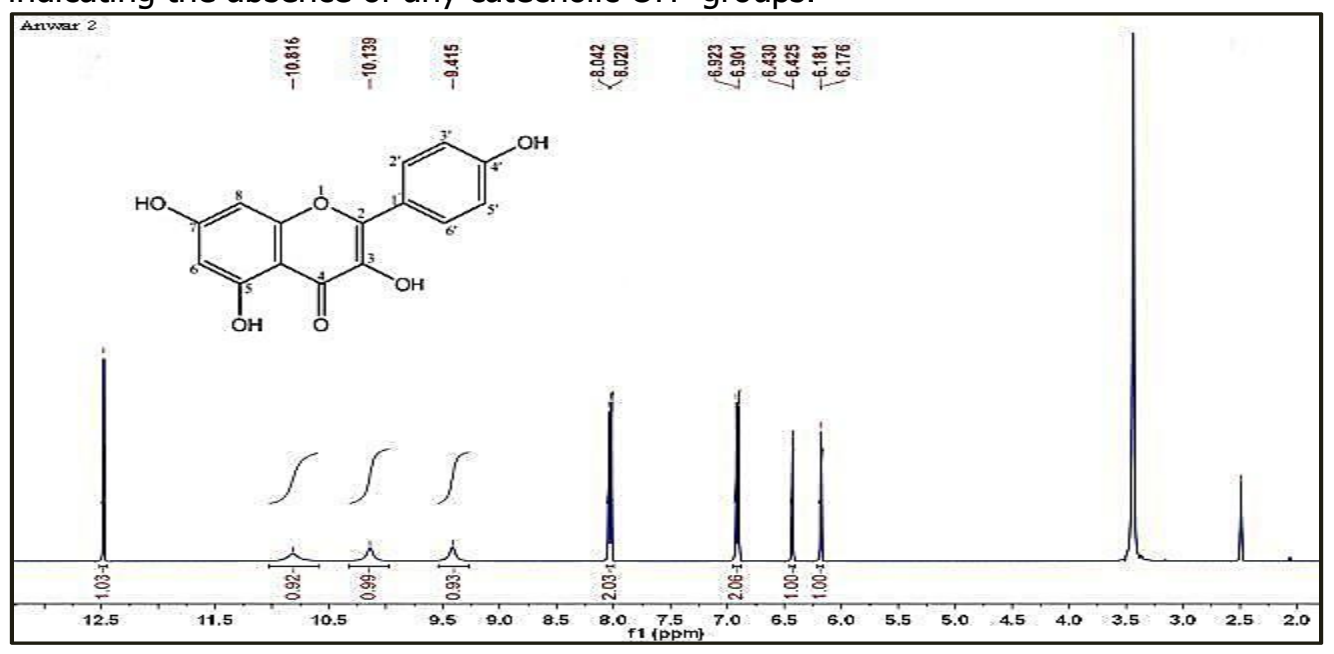

Fig. 2. ${ }^{1} \mathrm{H}-\mathrm{NMR}$ spectrum of compound 2 (Kaempferol).

The ${ }^{1} \mathrm{H}-\mathrm{NMR}$ spectrum of compound (2) is characteristic for flavonol as shown in Table (6) and Fig. (2), it showed two signals at $\delta 6.17(1 \mathrm{H}, d)$ and $6.42 \mathrm{ppm}(1 \mathrm{H}$, d) consistent with the meta protons $\mathrm{H}-6$ and $\mathrm{H}-8$ on A-ring and an $A A^{\prime}{ }^{\prime} B B^{\prime}$ system at $8.04\left(2 \mathrm{H}, d^{\prime}, \mathrm{H}^{\prime} 2^{\prime}\right.$ and $\left.\mathrm{H}-6^{\prime}\right)$ and $6.93\left(2 \mathrm{H}, d, \mathrm{H}-3^{\prime}\right.$ and $\left.\mathrm{H}-5^{\prime}\right)$ corresponding to the protons on B-ring. All mentioned spectral data showed that the compound (2) is Kaempferol which was isolated and identified previously from Cissus quadrangularis by Thakur et al., (2009).

\section{Structure elucidation of compound (3)}

Compound (3) was isolated and purified as yellow crystals. The UV spectrum in methanol showed two absorption bands at $\lambda_{\max }(275$ and $331 \mathrm{~nm})$ indicator for this compound is flavonol.

Table 4. UV-absorption spectrum of compound (3)

\begin{tabular}{|c|c|c|c|c|c|c|}
\hline Band & $\mathrm{MeOH}$ & $\mathrm{NaOH}$ & $\mathrm{NaOAC}$ & $\mathrm{NaOAc} / \mathrm{H}_{3} \mathrm{BO}_{3}$ & $\mathrm{AlCl}_{3}$ & $\mathrm{AlCl} / 3 / \mathrm{HCl}$ \\
\hline B-II & 275 & 285 & 280 & 280 & 285 & 285 \\
\hline B-I & 331 & 390 & 341 & 340 & $330,340 \mathrm{sh}$ & $330,340 \mathrm{sh}$ \\
\hline
\end{tabular}

In addition of sodium hydroxide caused a bathochromic shift of Band-I at $\lambda$ $\max (390 \mathrm{~nm})$, proved the presence of free $4 \backslash-\mathrm{OH}$ group. Also a bathochromic shift in 
Band-II at $\lambda_{\max }(285 \mathrm{~nm}$ ) indicated the presence of free $7-\mathrm{OH}$ group. In addition of sodium acetate a bathochromic shift which leads to absorption Band II at $\lambda_{\max }$ (280 $\mathrm{nm}$ ) and Band II (341 nm) indicating of free 7- hydroxyl group. Addition of boric acid caused no shift, which proved the absence of any catecholic $\mathrm{OH}$ groups.

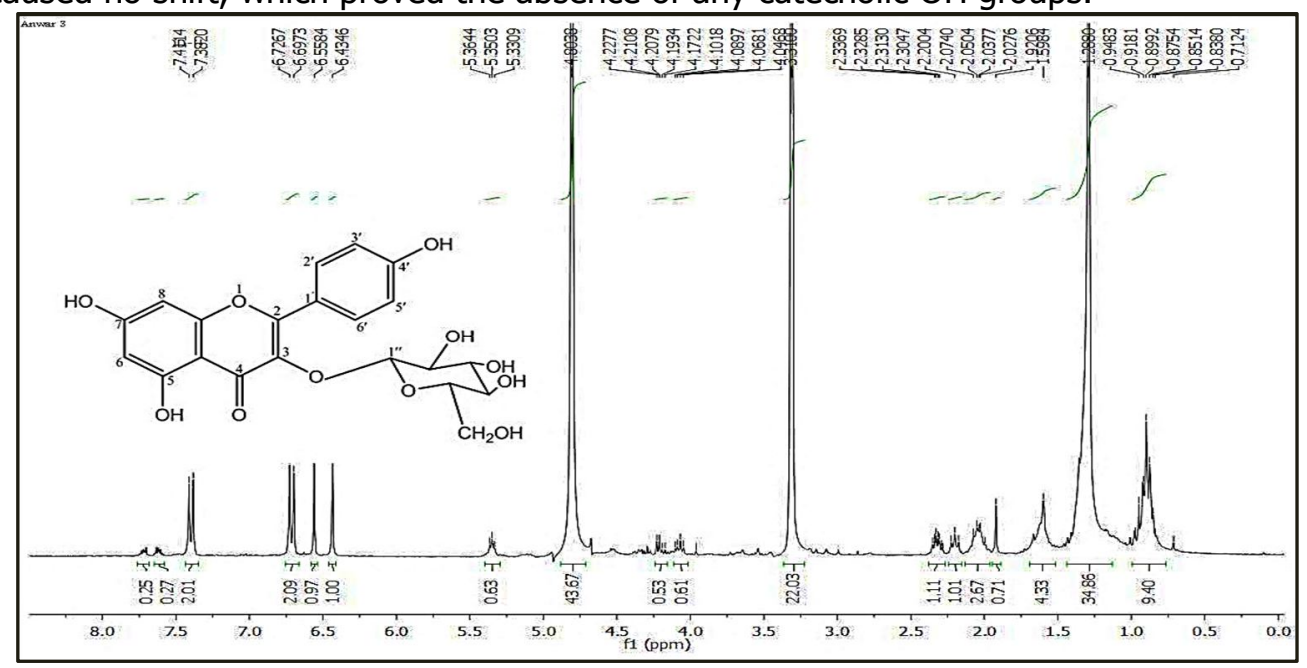

Fig. 3. ${ }^{1} \mathrm{H}-\mathrm{NMR}$ spectrum of compound 3 (kaempferol-3-O-glucoside).

The ${ }^{1} \mathrm{H}-\mathrm{NMR}$ spectrum is characteristic for flavonoid glycoside as shown in Table (6) and Fig. (3), it showed two signals at $\delta 6.42(1 \mathrm{H}, d)$ and $6.55 \mathrm{ppm}(1 \mathrm{H}, d)$ consistent with the meta protons $\mathrm{H}-6$ and $\mathrm{H}-8$ on $\mathrm{A}$-ring. $\mathrm{A} \mathrm{A}^{\prime} \mathrm{BB}^{\prime}$ system at $7.38(2 \mathrm{H}$, $d, \mathrm{H}-2^{\prime}$ and $\left.\mathrm{H}-6 \backslash\right)$ and $6.69\left(2 \mathrm{H}, d, \mathrm{H}-3^{\prime}\right.$ and $\left.\mathrm{H}-5^{\prime}\right)$ corresponding to the protons on $\mathrm{B}-$ ring. Compound 3 presented the same aglycone signal patterns of compound (2) but the signal at $\delta 4.803 \mathrm{ppm}(1 \mathrm{H}, d)$ followed by other characteristic additional signals indicates the presence of a sugar moiety in compound (3). It showed signal at $\delta$ (3.3 ppm, $m$ ), where the sugar moiety was determined to be glucose bound to the C-3 position of the aglycone by comparison of proton and carbon upfield shift values with the literature data of Awaad et al., (2004), the compound (3) was identified as kaempferol-3-O-glucoside.

\section{Structure elucidation of compound (4)}

Compound (4) was isolated and purified as yellow crystals. The UV spectrum in methanol showed two absorption bands at $\lambda_{\max }(255$ and $372 \mathrm{~nm}$ ) indicator for this compound is flavonol, as shown in Table (2). The Band II at $\lambda_{\max }(255 \mathrm{~nm})$ indicated the presence of two oxygen in B-ring.

Table 5. Ultra-Violet absorption spectrum of compound (4)

\begin{tabular}{|c|c|c|c|c|c|c|}
\hline Band & $\mathrm{MeOH}$ & $\mathrm{NaOH}$ & $\mathrm{NaOAc}$ & $\mathrm{NaOAc} / \mathrm{H}_{3} \mathrm{BO}_{3}$ & $\mathrm{AlCl}_{3}$ & $\mathrm{AlCl} / \mathrm{HCl}$ \\
\hline B-II & 255 & 243 & 255 & 262 & 273 & 273 \\
\hline B-I & 372 & 432 & $380,433 \mathrm{sh}$ & 390 & $340,434 \mathrm{sh}$ & $340,420 \mathrm{sh}$ \\
\hline
\end{tabular}

In addition of sodium hydroxide caused a hypsohochromic shift which leads to absorption Band-II at $\lambda_{\max }(243 \mathrm{~nm})$ indicated the 7-OH substituent. Moreover, caused a bathochromic shift of Band-I at $\lambda_{\max }(432 \mathrm{~nm})$, which proved the presence of free 4- OH group. 
After addition of sodium acetate, no bathochromic shift of spectrum in Band-II (255 $\mathrm{nm}$ ) indicated presence of $7-\mathrm{OH}$ substituent. After addition of boric acid caused a bathochromic shift in Band-I (390 nm), which proved the presence of catecholic $\mathrm{OH}$ groups.

In addition of aluminum chloride, a bathochromic shift of Band-I (434 nm) indicated the presence of free 5,3-OH groups. The hypsochromic shift of $\mathrm{AlCl}_{3}$ spectrum in Band-I (420 nm) after addition of $\mathrm{HCl}$, this indicated, this indicated presence of free ortho $3 \backslash, 4 \backslash$ hydroxyl groups in B-ring.

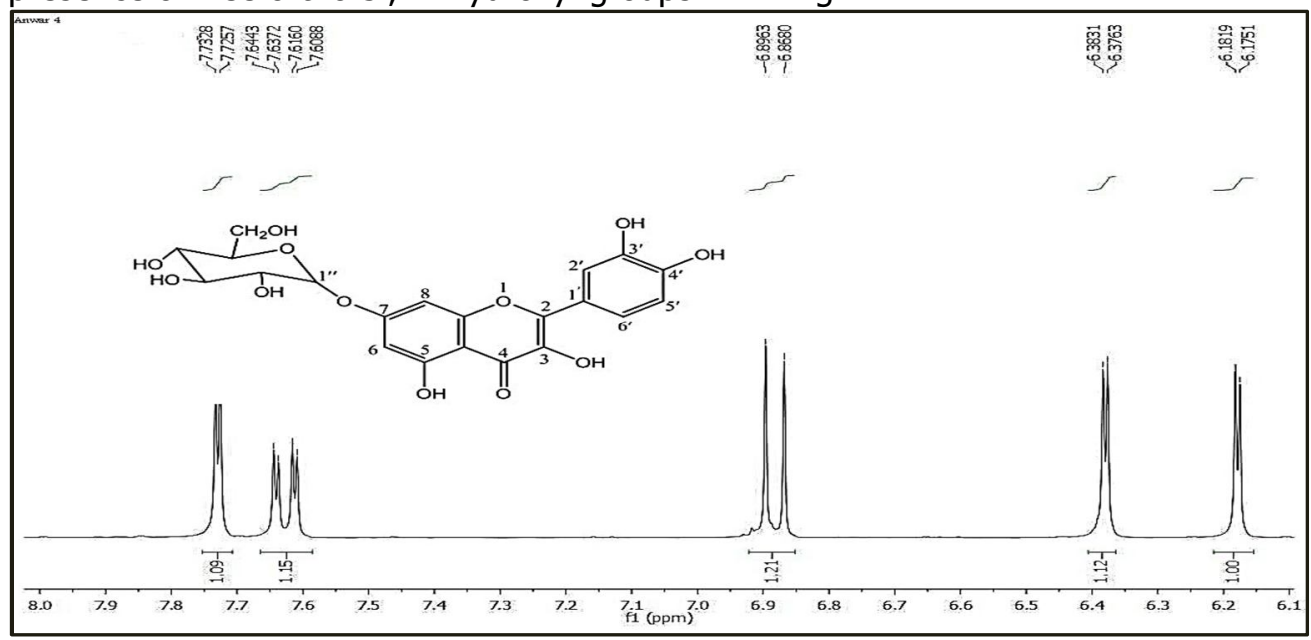

Fig. 4. ${ }^{1} \mathrm{H}-\mathrm{NMR}$ spectrum of compound 4 (Quercetin-7-O-g/ucoside).

The ${ }^{1} \mathrm{H}-\mathrm{NMR}$ spectrum of compound (4) was characteristic for favonol as shown in Table (6) and Fig. (4), it showed two signals at $\delta 6.18(1 \mathrm{H}, d)$ and $6.37 \mathrm{ppm}$ $(1 \mathrm{H}, d)$ consistent with the meta protons $\mathrm{H}-6$ and $\mathrm{H}-8$ on A-ring, On the other hand, the observation of $A B X$ system at $7.72\left(1 \mathrm{H}, d, \mathrm{H}^{\prime} 2^{\prime}\right), 7.64\left(1 \mathrm{H}, d d^{\prime}, \mathrm{H}-6^{\prime}\right)$, and 6.86 $\left(1 \mathrm{H}, d, \mathrm{H}-5^{\prime}\right)$ corresponding to the catechol protons on B-ring. 7-O-substituted flavonol was indicated for corresponding anomeric proton at $\delta 4.83 \mathrm{ppm}(1 \mathrm{H}-, d, \mathrm{H}-$ $\left.1^{\prime \prime}\right)$ characteristic for glucosyl moiety, upfield shift signal at $\delta 3.29 \mathrm{ppm}(1 \mathrm{H}, m$, glucosyl protons). All the previous spectral data of compound (4) showed that the compound is Quercetin-7-O-g/ucoside which was previously isolated and identified by Ying (2000).

Table 6. ${ }^{1} \mathrm{H}-\mathrm{NMR}$ spectra of isolated flavonoids recorded in $\mathrm{MeOH}$

\begin{tabular}{|c|c|c|c|c|}
\hline \multirow{2}{*}{$\mathrm{H}-$ atom } & $\begin{array}{c}\delta \text { value }(\mathrm{ppm}) \\
\text { multiplicity }\end{array}$ & $\begin{array}{c}\delta \text { value }(\mathrm{ppm}) \\
\text { multiplicity }\end{array}$ & $\begin{array}{c}\delta \text { value }(\mathrm{ppm}) \\
\text { multiplicity }\end{array}$ & $\begin{array}{c}\delta \text { value }(\mathrm{ppm}) \\
\text { multiplicity }\end{array}$ \\
\cline { 2 - 5 } & 1 & 2 & 3 & 4 \\
\hline 6 & $6.17(1 \mathrm{H}, d)$ & $6.17(1 \mathrm{H}, d)$ & $6.42(1 \mathrm{H}, d)$ & $6.18(1 \mathrm{H}, d)$ \\
\hline 8 & $6.37(1 \mathrm{H}, d)$ & $6.42(1 \mathrm{H}, d)$ & $6.55(1 \mathrm{H}, d)$ & $6.37(1 \mathrm{H}, d)$ \\
\hline 2 & $7.72(1 \mathrm{H}, d)$ & $8.04(1 \mathrm{H}, d)$ & $7.38(1 \mathrm{H}, d)$ & $7.72(1 \mathrm{H}, d)$ \\
\hline $3 \backslash$ & - & $6.93(1 \mathrm{H}, d)$ & $6.69(1 \mathrm{H}, d)$ & - \\
\hline $5 \backslash$ & $6.88(1 \mathrm{H}, d)$ & $6.93(1 \mathrm{H}, d)$ & $6.69(1 \mathrm{H}, d)$ & $6.86(1 \mathrm{H}, d)$ \\
\hline $6 \backslash$ & $7.61(1 \mathrm{H}, d d)$ & $8.04(1 \mathrm{H}, d)$ & $7.38(1 \mathrm{H}, d)$ & $7.64(1 \mathrm{H}, d d)$ \\
\hline $1^{11}$ & - & - & $4.803(1 \mathrm{H}, d)$ & $4.83(1 \mathrm{H}, d)$ \\
\hline $\begin{array}{c}\text { Glucosyl } \\
\text { protons }\end{array}$ & - & - & $3.3(1 \mathrm{H}, m)$ & $3.291 \mathrm{H}, m)$ \\
\hline
\end{tabular}




\section{Biological studies}

In our screening program which is designed to evaluate the biological activity of ethanolic extract of $B$. napus leaves, it was found that the extract showed toxicity against the $4^{\text {th }}$ instar larvae of $S$. littoralis under lab-conditions using leaf dipping technique, where the larvae fed on treated castor bean leaves for $48 \mathrm{hrs}$ then transferred to untreated ones.

Table 7. Insecticidal activity of ethanolic extract of $B$. napus leaves against the $4^{\text {th }}$ instar larvae of $S$. littoralis.

\begin{tabular}{|c|c|c|c|}
\hline parameter & $\begin{array}{c}\mathrm{LC}_{25} \\
(\mathrm{gm} / 100 \mathrm{ml})\end{array}$ & $\begin{array}{c}\mathrm{LC} 50 \\
(\mathrm{gm} / 100 \mathrm{ml})\end{array}$ & Slope $\pm \mathrm{SE}$ \\
\hline 7-Days post treatment & $\begin{array}{c}0.064 \\
(0.013-0.120)\end{array}$ & $\begin{array}{c}0.455 \\
(0.315-0.751)\end{array}$ & $0.794 \pm 0.19$ \\
\hline & & & 0.091 \\
14-Days post treatment & 0.016 & $(0.031-0.146)$ & $0.91 \pm 0.20$ \\
\hline
\end{tabular}

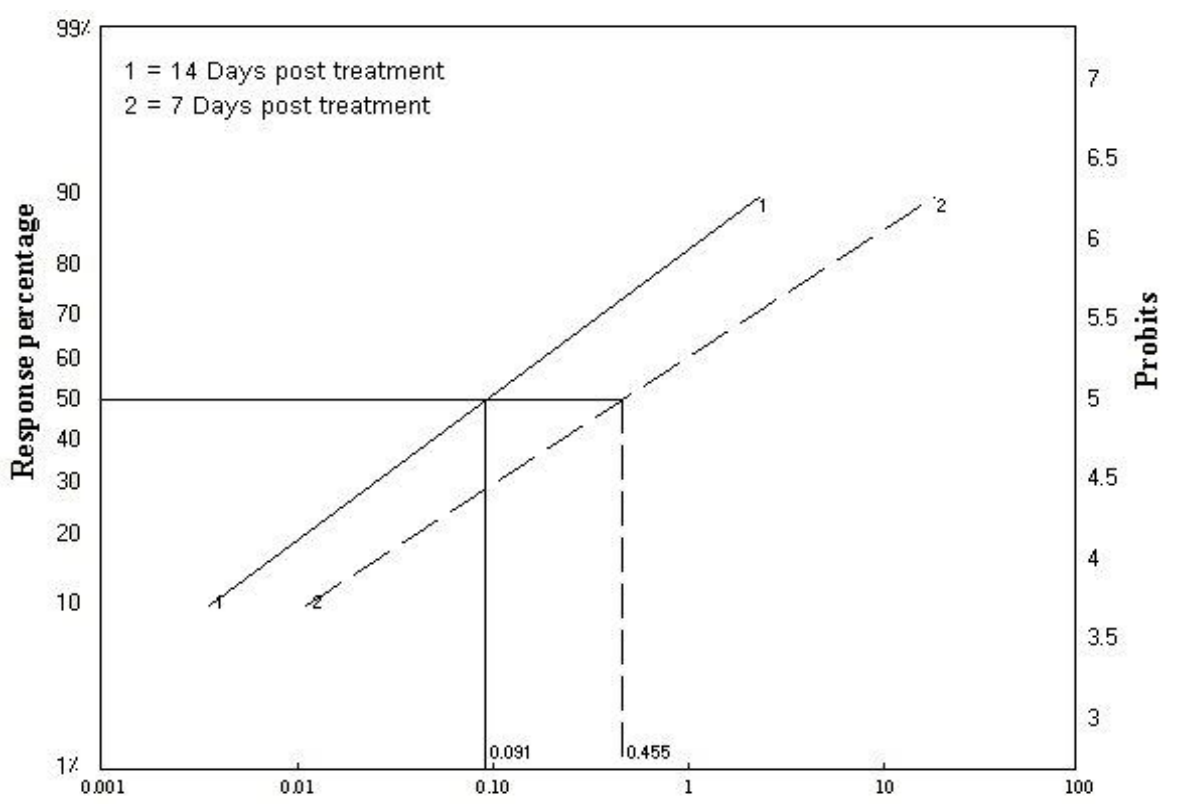

Fig. 5. comparative toxicity lines of ethanolic extract of $B$. napus leaves against the $4^{\text {th }}$ instar larvae of $S$. littoralis at 7 and 14 - days post treatment.

By using LC-P program; LC25, LC 50 and their confidence limits, and slope values were used as parameters in evaluation the insecticidal activity of tested extract, where mortality of larvae was recorded daily and accumulative larval mortality was recorded. It was observed that the toxicity increased with concentrations used and time post treatment according to descending order of $\mathrm{LC}_{25}$ and $\mathrm{LC}_{50}$ values, where $\mathrm{LC}_{25}$ values were $(0.064$ and $0.019 \mathrm{gm} / 100 \mathrm{ml})$ at 7 and 14 days post treatment, respectively. Also $L_{50}$ values were $(0.455$ and $0.091 \mathrm{gm} / 100 \mathrm{ml})$ at 7 and 14 days post treatment, respectively. Furthermore, when the lower and upper confidence 
limits were taken into consideration, it was found that all the points of $\mathrm{LC}_{25}$ and $\mathrm{LC}_{50}$ values were within these limits, as presented in Table (7) and Fig. (5).

Flavonoids are reported as a major class of phytochemicals constituting 5$10 \%$ of the known secondary metabolites in plants. They are involved, beside other things, in plant defense mechanisms by exerting toxic effects on insects, where to date, more than 5000 flavonoids are documented and their antimicrobial and insecticidal activities demonstrated (Kotkar et al., 2002). The insecticidal activity of flavonoids is mainly the result of inhibition of vital enzymatic pathways, such as the actions of cytochrome- $P_{450}$ dependent oxidases, in which affect insect ecdysone-20 monoxygenase, which is responsible for the biosynthesis of 20-hydroxyecdysone (Mitchell et al., 1993), whereas the antimicrobial activity of flavonoids is attributed to changes in membrane structure (Padmavati and Reddy, 1999). Where Kuroyanagi et al., (1999) found that flavonoids of Thea sinensis and Sophora flavescens have shown promising antimicrobial activity against gram-positive bacteria, Staphylococcus aureus Rosenbach and Bacillus subtillis (Ehrenberg) Cohn.

Quercetin and other pro-oxidant compounds can be metabolically activated to generate free radical species in insects upon ingestion. Their generation can result in direct cellular toxicity, or give rise to more toxic oxygen species and hydroxyl by oxygen radical cascade (Mendki et al., 1999).

From all mentioned results, it can concluded that the ethanolic extract of $B$. napus leaves and its flavonoids can be used effectively as botanical insecticide to control the cotton leafworm, $S$. littoralis, where $B$. napus leaves is by- product from the plant.

\section{REFERENCES}

1. Abbott, W.S. 1925. A method of computing the effectiveness of an insecticide. J. Econ. Entomol., 18: 265-267.

2. Awaad, A. S.; Y. A. H. Osman; D. J. Maitland and G. A. Soliman. 2005. Comparative study on antioxidant activity of cultivated and wild Bidens bipinnata Linne plant, J. Natur. Prod., 9: 1-8.

3. Chu, Y. H.; C. L. Chang and H. F. Hsu. 2000. Flavonoid content of several vegetables and their antioxidant activity. J. Sci. Food Agric., 80: 561-566.

4. Dhasan P. B.; M. Jegadeesan and S. Kavimani. 2008. Cucurbitacins isolated from the fruits of Momordica cymbalaria Hook f. Pharmacogn Mag., 4: 96-101.

5. El-Defrawi, M. E.; A. Toppozada; N. Mansour and M. Zeid. 1964.Toxicological studies on the Egyptian cotton leafworm, Prodenia litura (F.) I. Susceptibility of different larval instars of prodenia to insecticides. J. Econ. Entomol., 57: 591-593. 
6. Harborne, J. B. 1984. Phytochemical Methods (ed.). Chapman and Hall. London

7. Harborne, J. B. 1998. Phytochemical methods. A guide to modern techniques of plant analysis. 3rd edition. Chapman and Hall, London.

8. Harborne, J. B. and T. J. Mabry. 1982. The flavonoids: advances in research. Chapman and Hall. London

9. Harmala, P.; H. Vuorela; K. Tornquist and R. Hiltunen. 1992. Choice of solvent in the extraction of Angelica archangelica roots with reference to calcium blocking activity. Planta Medica., 58: 176-183.

10. Horowitz, R. M. and L. Jurd. 1961. Spectral Studies on Flavonoid Compounds. II. Isoflavones and Flavanones1a. J. Organic. Chem., 26 (7): 2446-2449.

11. Isman, M. B. and C. M. Machial. 2006. pesticides based on plant essential oils: from traditional practice to commercialization. In M. Rai and M.C. Carpinella (eds.), Naturally Bioactive Compounds, Elsevier, BV, PP 29-44.

12. Jangaard, N. O. 1970. Thin-layer chromatography of some plant phenolics. J. Chromatog., 50: 146-148.

13. Kessler, A. and I. T. Baldwin. 2002. plant responses to insect herbivory: the emerging molecular analysis. Annual Review of Plant Biology, 53: 299-328.

14. Kotkar H. M.; P. S. Mendki; S. V. Sadan; S. R. Jha; S. M. Upasani and V. L. Maheshwari. 2002. Antimicrobial and pesticidal activity of partially purified flavonoids of Annona squamosa. Pest Manag Sci., 58: 33-37.

15. Kuroyanagi M; T. Arakawa; Y. Hirayama and T. Hayashi. 1999. Antibacterial and antiandrogen flavonoids from Sophora flavescens. J. Nat. Prod., 62: 1595-1599.

16. Mabry, T. J.; K. R. Markham and M. B. Thomas, M. 1970. The systematic identification of flavonoids. In Library of Congress Catalog Card, No. 72-95565, p. 41.

17. Mears, J. A. and T. J. Mabry. 1972. A procedure for the UV detection of hydroxyl and methoxyl groups at C6-sub in flavones and 3-O-substituted flavonols. Phytochem., 11 (1): 411-412.

18. Mendki, P. S.; S. B. Patil; S. V. Patil; M. G. Patil; S. G. Patil; V. L. Maheshwari and R. M. Kothari. 1999. Pesticidal activity of certain plant extracts to control stored grain pest Callosobruchus chinensis. Pestol. 23: 64-67.

19. Mitchell J. M.; D. P. Keogh; J. R. Crooks and S. L. Smith. 1993. Effects of plant flavonoids and other allelochemicals on insect cytochrome P-450 dependent steroid hydroxylase activity. Insect Biochem Mol Biol., 65: 65-71.

20. Ncube, N.; S. A. J. Afolayan and A. I. Okoh. 2008. Assessment techniques of antimicrobial properties of natural compounds of plant origin: Current methods and future trends. African J. of Biotechnol., 7: 1797-1806. 
21. Nijveldt R. J.; E. van Nood ; D. E. C. van Hoorn; P. G. Boelens; K. van Norren and P. A. M. van Leeuwen. 2001. Flavonoids: a review of probable mechanisms of actions and potential applications. Am. J. Clin. Nutr., 74: 418.

22. Padilla G; M. E. Cartea; P. Velasco; A. de Haro and A. Ordas. 2007. Variation of glucosinolates in vegetable crops of Brassica rapa. Phytochem. 68: 536-545.

23. Padmavati, M. and A. R. Reddy. 1999. Flavonoid biosynthetic pathway and cereal defense response: An emerging trend in crop biotechnology. J Plant Biochem Biotechnol., 8: 15-20.

24. Sofowara, A. 1993. Screening plants for bioactive agents. In: Medicinal Plants and Traditional Medicinal in Africa, second ed., Spectrum Books Ltd., Sunshine House, Ibadan, Nigeria, pp. 134-156.

25. Thakur A.; V. Jain; L. Hingorani and K. S. Laddha. 2009. Phytochemical studies on Cissus quadrangularis Linn. Pharmacogn Res. 1: 213-5.

26. Ying, M. C. 2000. Phytochemical Studies on Chienese Medicinal plants: Hyoscyamus niger, Euptelea pleiospermum, and Rorippa Montana, Ph.D, Hong Kong Univ. Sci. \& Technol. 

BRASSICA NAPUS LEAVES EXTRACT WITH PROMISING BIOLOGICAL ACTIVITY TO CONTROL THE COTTON LEAFWORM, SPODOPTERA LITTORALIS (BOISD.)

\section{فصل وتعريف الصيخ البنائية للفلافونيدات المسئولة عن خاصية الدفاع الذاتية من} مستخلص أوراق نبات الكانولا التى لها تأتير بيولوجى لمكافحة دودة ورق لفئن القطن

$$
\text { أنــوار محمد ابـاظــة }
$$

معزُ بحوث وقاية النباتات، مركز البحوث الزراعية، الدقى، مصر

$$
\begin{aligned}
& \text { يحتوى نبات الكانو لا على مركبات عضوية طبيعية لها دور فى الدفاع عنه ضد الافات و }
\end{aligned}
$$

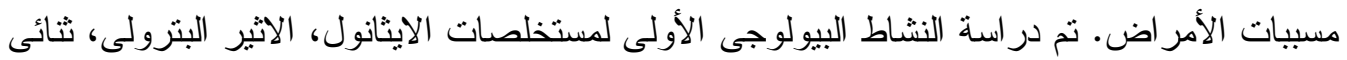

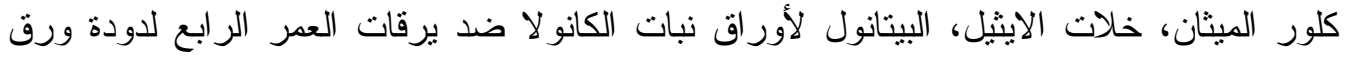

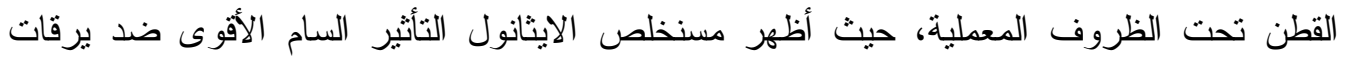

$$
\begin{aligned}
& \text { دودوة ورق القطن. نم التعرف على المكونات الموجودة فى اوراق نبات الكانولا حيث وجد أن }
\end{aligned}
$$

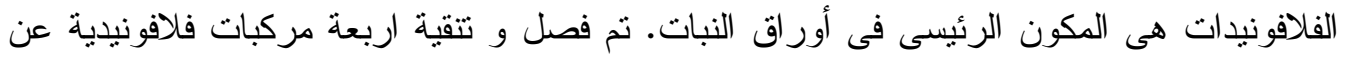

$$
\begin{aligned}
& \text { طريق طرق الفصل الكروماتوجر افية. وتم التعرف على الصيخ البنائية لها عن طريق استخدام } \\
& \text { القياسات الطيفية مثل الأشعة الفوق بنفسية وطيف الرنين النووى المغناطيسى للهيدروجين وهم: } \\
& \text { نuercetin Kaempferol, Kaempferol-3-O-glucoside, Quercetin-7-O-glucoside } \\
& \text { نتائج دراسة سمية لمستخلص الايثانول ان سمية المستخلص تزداد بمرور الوقت بعد المعاملة حيث }
\end{aligned}
$$

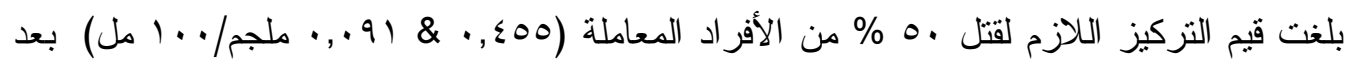

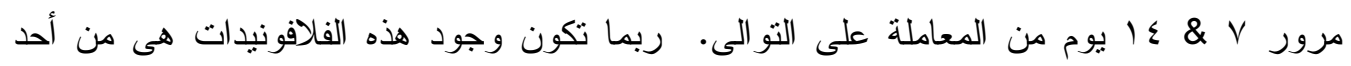

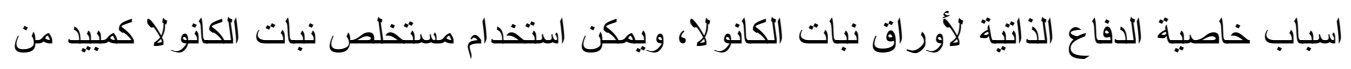

$$
\begin{aligned}
& \text { أصل طبيعى لمكافحة دودة ورق القطن. }
\end{aligned}
$$

